\title{
Remittances and Private Investment: Evidence in Asia and The Pacific Developing Countries
}

\author{
Le Thanh Tung* \\ Faculty of Business Administration, Ton Duc Thang University, No 19, Nguyen Huu Tho street, \\ Tan Phong ward, district 7, Ho Chi Minh city, Vietnam \\ *Corresponding author: lethanhtung@tdtu.edu.vn
}

\begin{abstract}
Although remittances have increased rapidly in recent decades, however. most previous studies have been done using micro-level data but there is no article employed data at the macro-level in Asia-Pacific. Our paper tries to fill the empirecal gap related to the impact of remittances on private investment in recipient countries with the panel data of 30 Asia and the Pacific developing countries in the period of $1985-2014$. The results confirmed that remittances lead to an increase in private investment in these countries but the quantitative analysis showed that this promoting impact is only a quite weak. Further more, our Granger causality test explored that there is only one-way causality from remittance to private investment existing in research period.
\end{abstract}

Keywords: Remittances, Private investment, Asia and the Pacific developing countries JEL Classification: E2, F6

\section{Introduction}

In recent three decades, remittance is one of the most important sources of foreign capital into the economy of developing countries in the world. Especially, remittance inflows play a significant role for the developing countries. In addition, remittances also create a financial connection more and more closely among countries, regions and continents over the world. Remittance inflows can be defined as current transfers sent by non-resident workers from the overseas to recipient countries (Chowdhury, 2011). According to World Bank (World Development Indicator), global remittances were reported to be approximately USD 583 billion in 2014, and the developing countries received over USD 436 billion in particular (accounting for 74.7 percent). In addition, the remittance inflow to the developing world is forecasted to exceed USD 516 billion by 2016 with an annual growth rate by 8.4 percent in the period 2014-2016. It was noteworthy that Asia and the Pacific region has been the region with the world's largest remittance inflows within 10 years.

Remittance inflows in the Asia-Pacific region has increased 14 times, from USD 14.2 billion in 1990 up to USD 198.2 billion in 2010. In 2013, remittances via official channels were around USD 235 billion in Asia and the Pacific, accounting for 45 percent of the total amount of remittances in the world. In Asia and the Pacific, there are 18 countries with the ratio of remittances over GDP was greater than 1 percent in 2013. Especially there are 9 countries with the ratio of remittance inflows to GDP more than 10 percent such as Tajikistan 47.5 percent, Kyrgyz Republic 30.7 percent or Nepal 28.7 percent. Since 1995, remittances have become the second largest foreign capital source (after foreign direct investment) into the Asia-Pacific region. In 2012, the remittance inflows in this region increased up to USD 236.6 billion in comparison with foreign direct investment (USD 557.1 billion) and official development assistance (USD 33.9 billion). 
There have been many studies on the positive role of remittances in an economy, but only a few results focused on the relationship between remittances and private investment in the recipient countries. Remarkably, there are few studies on the effects of remittances on private investment at the macro level, but many experimental results at the micro level including Massey and Parrado (1998) studied in Mexico, Adams and Cuecuecha (2010, 2013) experimented in Guatemala and Ghana, Mallick (2012) studied in India, or Salas (2014) implemented in Peru. Following the literature there has been no experimental evidence for the impact of remittances on private investment in the Asia-Pacific region.

The findings of this paper contribute to the theoretical background of remittances in the two following ways. Firstly, empirical evidence clarifies the relationship between remittances and private investment and proves the direct impact of remittances on the economic growth in the recipient countries. Secondly, previous studies only used data at the micro-level, whereas this research employed data at the macro-level via using a sample of 32 developing countries in Asia and the Pacific region.

The structure of this paper includes five sections. Section 2 presents an overview of the literature and empirical investigations. The econometric model and data description are introduced in Section 3. Section 4 shows the main results and discussion. The results of Granger causality test is represented in the Section 5. Finally, Section 6 presents conclusions and some policy implications.

\section{Literature Review}

Remittance is a large capital inflow from foreign countries into the economy of the recipient countries, in which most of the remittances are transferred to the household sector. Recently, many studies have shown that remittances promote economic growth (Giuliano \& Ruiz-Arranz, 2009) and help to reduce poverty (Acosta et al., 2008; Gupta et al., 2009; Imai et al., 2014).

Besides, remittances were found to contribute to the expansion of the financial sector in many countries (Chowdhury, 2011; Aggarwal et al., 2011; Cooray, 2012; Beine et al., 2012) or increase the competitiveness of an economy (Bayangos \& Jansen, 2011). However, remittances were also found to have negative impacts on the economy of the recipient countries such as social inequality (Acosta et al., 2008), corruption (Berdiev et al., 2013) or inflation (Narayan et al, 2011).On the other hand, the relationship between remittances and private investment is still an infrequent topic in the literature review, and the studies are mostly based on micro-level data in some US-Latin or Africa countries. Moreover, these studies showed inconsistent or even contradictory results. According to Massey and Parrado (1998), remittances from U.S accounted for 21 percent in start-up capital of The New Business Formation in Mexico. In addition, Conway and Cohen (1998) found that remittances promote and support manufacturing companies in the Santa Anan community in Mexico. Therefore, both of the above mentioned studies proved the impact of remittance on promoting private investment in the recipient countries.

Adams and Cuecuecha (2010) used household survey data in Guatemala in the period from July to December 2000 to investigate the impact of remittances on households' marginal consumption by the application of the Working-Lesser model and the Two-Stage Selection Model. The research results concluded that households receiving remittances increase investment in education and housing. Adams and Cuecuecha (2013) experimented with household survey data in Ghana from September 2005 to September 2006 and found that remittances increase household investment in not only housing and education but also health care. Consequently, the results of this experimental study supported the theoretical framework of the impact of remittances on investment in human and physical capital in the recipient countries. Baldé (2011) investigated the impact of remittances on savings and investment using a sample of 37 and 34 Sub-Saharan Africa (SSA) countries over the period 1980-2004. The results found that remittance inflows have a positive and significant impact on investment in SSA region. The study also indicated that the amount and ratio of 
remittances are lower than foreign aid, but remittances have more positive impact on investment.

On the contrary, Mallick (2012) conducted research on the relationship between remittance inflows and private investment in India from 1966 to 2005. The results proved that remittances have a negative impact (or detrimental effect) on private investment in India in the study period. On the basis of the research findings, it is suggested that the Indian government should have appropriate policies regarding remittance inflows to the private sector for promoting the economic growth rate. Continuously, Ahamada and Coulibaly (2013) applied the panel Granger causality testing approach to investigate the causal relationship between remittance inflows and economic growth over the period 1980-2007 in the case of 20 countries in the Sub-Saharan African region. However, the research findings showed that there is no relationship between remittance inflows and economic growth because remittances did not increase physical capital investment in these countries.

More recently, Salas (2014) used the human capital theory and Random - Effects Probit Model for analyzing the role of remittances toward household's decision on investment in children education in Peru from 2007 to 2010. The results found that remittances have a positive effect on human capital investment in the research period. Similarly, Bedi and Sparrow (2009) examined the influence of remittance on human capital investment in Ecuador from 2005 to 2006 and their research findings concluded that remittances play a role as an investment resource for human capital. Davis and Lopez-Carr (2014) applied the modern economics of labor migration framework to examine the relationship between migration, remittances and smallholder decision-making in land use and livelihood change for the case of four countries in Central America, including Costa Rica (2002), El Salvador (2007), Guatemala (2004) and Nicaragua (2002). The results presented that remittances lead to a growth in private investment in agriculture in these countries.

\section{Methodology and Data Description}

\subsection{Econometric model}

According to the econometric model in the previous studies by Baldé (2011) and Adam (2009), the econometric model for analysis the impact of remittances on private investment in Asia and the Pacific developing countries in this research is constructed as follows:

$\mathrm{PINV}_{\mathrm{i}, \mathrm{t}}=\beta_{0}+\beta_{1} \mathrm{PINV}_{\mathrm{i}, \mathrm{t}-1}+\beta_{2} \mathrm{GDPG}_{\mathrm{i}, \mathrm{t}}+\beta_{3} \mathrm{REM}_{\mathrm{i}, \mathrm{t}}+\beta_{4} \mathrm{GE}_{\mathrm{i}, \mathrm{t}}+\beta_{5} \mathrm{OPENNESS}_{\mathrm{i}, \mathrm{t}}+\varepsilon_{\mathrm{i}}$

Where, PINV $\mathrm{i}_{\mathrm{i}, \mathrm{t}}$ denotes private investment variable referring to the Gross fixed capital formation over GDP; PINV $\mathrm{i}_{\mathrm{i}, \mathrm{t}-1}$ is the lag of private investment; GDPG $\mathrm{i}_{\mathrm{i}, \mathrm{t}}$ represents the economic growth rate, $\mathrm{REM}_{\mathrm{i}, \mathrm{t}}$ denotes the ratio of remittances over GDP; $\mathrm{GE}_{\mathrm{i}, \mathrm{t}}$ is the ratio of Government expenditure over GDP; OPENNESS $\mathrm{i}_{\mathrm{i}, \mathrm{t}}$ measures the trade openness of the economy (calculated by the sum of exports and imports over GDP) and $\varepsilon$ is the error term. Continuously, $t$ denotes periods, and $\mathrm{N}$ is cross-sectional units with $\mathrm{i} \epsilon[1, \mathrm{~N}]$.

This study employs panel data to estimate the coefficients of the variables in the equation (1) with the application two estimation methods such as Ordinary Least Squares (OLS) and Two-Stage Least Squares (2-SLS) for testing the relationship between remittances and private investment in Asia and the Pacific developing countries. In addition, the 2-SLS method is applied with the aim of controlling for endogeneity in the research model and the results of OLS method is used for comparison. This study applies three econometric models in each regression method, including (1) Pooled Model (PM), (2) Fixed Effects Model (FEM), and (3) Random Effects Model (REM). Continuously, the estimated models are tested for validity by the F-test and the Hausman tests. The F-test is employed to examine the validity of FEM in comparison with the PM. The validity between REM and FEM is also concluded using the Hausman-test. 


\subsection{Data description}

The research used annual data from 1985 to 2014 in 30 Asian and the Pacific developing countries. The data are extracted from the World Development Indicators database of World Bank. Table 1 shows the description of the variables in this research.

Table 1. Descriptive statistics

\begin{tabular}{lllllll}
\hline Statistics & Mean & Median & Maximum & Minimum & Std.dev & Observations \\
\hline PINV & 26.48 & 24.47 & 93.13 & 5.18 & 9.95 & 656 \\
REM & 4.14 & 1.57 & 49.29 & 0.03 & 6.58 & 656 \\
GDPG & 5.45 & 5.61 & 34.5 & -20.09 & 4.91 & 656 \\
GE & 0.12 & 0.11 & 0.39 & 0.03 & 0.04 & 656 \\
OPENNESS & 0.83 & 0.69 & 4.58 & 0.11 & 0.62 & 656 \\
\hline
\end{tabular}

Notes: PINV $\mathrm{i}_{\mathrm{i}, \mathrm{t}}$ is the private investment over GDP; $\mathrm{REM}_{\mathrm{i}, \mathrm{t}}$ is the remittances over GDP; $\mathrm{GDPG}_{\mathrm{i}, \mathrm{t}}$ is the economic growth rate; $\mathrm{GE}_{\mathrm{i}, \mathrm{t}}$ is the Government expenditure over GDP; OPENNESS $\mathrm{i}_{\mathrm{i}, \mathrm{t}}$ is the trade openness of the economy.

\subsection{Correlation amongst variables}

The correlation between amongst variables in the equation (1) is shown in Table 2. There are a number of issues discovering through this analysis. Firstly, the relationship between remittance and private investment has a positive sign, however, the result shows that this relationship seems a bit weak (0.0400). Besides, both economic growth and government expenditure have a positive relationship with investment, which reflects the growth and public expenditure playing a role in supporting private investment. Finally, trade openness has a negative relationship with private investment showing that the open tendency of the economy hasn't promoted the private development sector Asian and the Pacific Asian developing countries in the study period.

Table 2. Correlation coefficients amongst variables

\begin{tabular}{lccccc}
\hline & PINV & REM & GDPG & GE & OPENNESS \\
\hline PINV & 1.0000 & & & & \\
REM & 0.0400 & 1.0000 & & & \\
GDPG & 0.2183 & -0.0286 & 1.0000 & & \\
GE & 0.1511 & 0.0059 & -0.1804 & 1.0000 & \\
OPENNESS & -0.0081 & -0.1111 & 0.0223 & 0.0248 & 1.0000 \\
\hline
\end{tabular}

Notes: PINV $\mathrm{i}_{\mathrm{i}, \mathrm{t}}$ is the private investment over GDP; $\mathrm{REM}_{\mathrm{i}, \mathrm{t}}$ is the remittances over GDP; $\mathrm{GDPG}_{\mathrm{i}, \mathrm{t}}$ is the economic growth rate; $\mathrm{GE}_{\mathrm{i}, \mathrm{t}}$ is the Government expenditure over GDP; OPENNESS $_{\mathrm{i}, \mathrm{t}}$ is the trade openness of the economy.

\section{Empirical Results and Discussion}

Remittance is a foreign currency flowing into the household sector. Therefore, remittance increases not only household's consumption but also investment private in an economy, which will increase aggregate demand in the economy. Continuously, private investment impacts on the gross domestic product with a multiplier effect on aggregate demand. Besides, remittance is a foreign currency inflow to Asia and the Pacific developing countries, which will increase the total of the medium of exchange in these countries. Therefore, the remittance will lead to an increase in money supply in the economy because of many Asian - Pacific developing countries allow people to settle payment by foreign currency. Accordingly, the empirical research result is expected that the remittance flow will 
have a positive impact on private investment in the developing countries of Asia- Pacific region.

According to our econometric strategies, the panel data are estimated using two estimation methods, including OLS and 2-SLS. All regression coefficients presenting the relationship among the variables in the equation (1) are shown in Table 3 and Table 4. The results indicate the positive relationship between remittances and private investment using both OLS and 2-SLS.

Table 3. Ordinary Least Squares (OLS) estimation results

\begin{tabular}{llll}
\hline & PM & FEM & \multicolumn{1}{c}{ REM } \\
\hline PINV(-1) & $0.865735^{* * *}$ & $0.653383 * * *$ & $0.865735 * * *$ \\
& $(288.5771)$ & $(21.91484)$ & $(50.86491)$ \\
GDPG & $0.196767 * * *$ & $0.194296^{* * *}$ & $0.196767 * * *$ \\
& $(31.93090)$ & $(5.075411)$ & $(5.628175)$ \\
REM & $0.028921^{* * *}$ & $0.197858 * * *$ & 0.028921 \\
& $(6.515891)$ & $(4.525275)$ & $(1.148498)$ \\
GE & $5.292089 * * *$ & -10.77914 & 5.292089 \\
& $(7.736188)$ & $(-1.266440)$ & $(1.363589)$ \\
OPENNESS & $-0.085268 *$ & 0.538882 & -0.085268 \\
& $(-1.837512)$ & $(0.659998)$ & $(-0.323882)$ \\
\hline Constant & $2.014799^{* * *}$ & $8.326488 * * *$ & $2.014799 * * *$ \\
& $(16.53222)$ & $(5.866426)$ & $(2.913987)$ \\
\hline Observations & 641 & 641 & 641 \\
F-statistic & & $3.060777[0.000]$ & \\
Hausman test $(\chi 2)$ & & & $81.725577[0.0000]$ \\
$\mathrm{R}^{2}$ & 0.8053 & 0.8310 & 0.8053 \\
\hline
\end{tabular}

Notes: $\mathrm{t}$-statistics are in parentheses below the coefficients; * significant at 10percent; $* *$ significant at 5percent; *** significant at 1percent. PM denotes the pooled model; FEM denotes the fixed effects model; REM denotes the random effects model.

Table 4. Two-Stage Least Squares (2-SLS) estimation results

\begin{tabular}{llll}
\hline & PM & FEM & \multicolumn{1}{c}{ REM } \\
\hline PINV(-1) & $1.098904 * * *$ & $1.476472 * * *$ & $1.098904 * * *$ \\
GDPG & $(288.5771)$ & $(21.91484)$ & $(38.16179)$ \\
& $0.109939 * * *$ & $0.104903 *$ & $0.109939 * *$ \\
REM & $(15.76551)$ & $(1.814759)$ & $(2.084851)$ \\
& $0.024102 * * *$ & -0.085294 & 0.024102 \\
GE & $(4.819632)$ & $(-1.254947)$ & $(0.637354)$ \\
& $-4.189652 * * *$ & -14.93883 & -4.189652 \\
OPENNESS & $(-5.413004)$ & $(-1.167355)$ & $(-0.715822)$ \\
& -0.024204 & -0.579685 & -0.024204 \\
Constant & $(-0.462939)$ & $(-0.471563)$ & $(-0.061220)$ \\
& $-2.524760 * * *$ & $-10.20229 * * *$ & $--2.524760 *$ \\
Observations & $(-17.84425)$ & $(-4.223674)$ & $(-2.359745)$ \\
F-statistic & 641 & 641 & 641 \\
Hausman test $(\chi 2)$ & & $6.566[0.000]$ & \\
R2 & & & $40.760912[0.0000]$ \\
\hline
\end{tabular}

Notes: t-statistics are in parentheses below the coefficients; $*$ significant at 10percent; ** significant at 5percent; *** significant at 1percent. PM denotes the pooled model; FEM denotes the fixed effects model; REM denotes the random effects model. 
All regression coefficients describing the relationships among variables in investment function are presented in Table 3 and Table 4. The OLS estimation results show that remittances (REM) have the positive effects on private investment (PINV) using both PM and FEM at the 1 percent significance level. Meanwhile, the estimated coefficient of remittance to private investment from REM is a positive sign but statistically insignificant. However, the 2-SLS estimation results represent the existence of a positive relationship between remittances and private investment also with FM model, significant at the 1 percent level. These findings affirm that remittances promote private investment in Asia and the Pacific developing countries over the research period. This finding contributes the theoretical framework and is consistent with the previous findings by Balde (2011), Adams and Cuecuecha (2013). The results provide the policy-makers in these countries with sufficient evidence on the role of remittances on private investment in their economies.

The results indicate that the current private investment has a positive relationship with the previous private investment using both OLS (significant at the 1 percent level with PM, FEM and REM) and 2-SLS methods (significant at the 1 percent level with the PM). This is an evidence of inertia phenomenon of private investment in an economy. The results also confirm that the economic growth rate (GDPG) has a positive relation with private investment at 1 percent level of significance with the application of both OLS and 2-SLS methods. The results find that government expenditure (GE) has a positive relationship with private investment in the research period. The estimated coefficients of government expenditure (GE) are found to be positive and significant at the 1 percent level with 2-SLS estimations (only PM) and OLS (only PM). These results indicate that higher government expenditure tends to increase private investment in the economy. However, the sign of the estimated coefficient of trade openness (OPENNESS) is negative and significant at the 10 percent level using the PM of OLS estimation. Therefore, this evidence implies that the relationship between private investment and trade openness is not so strong as some other variables in the above mentioned investment function.

\section{Panel Causality Test Results}

In this part of our paper, the panel Granger causality test was used to analysis the existence of the causal relationships between some explanatory variables and private investment in Asian and the Pacific developing countries. Although Granger causality testing standards were explored by Granger (1969), supposed to be inappropriate for panel data. However, our article applies the Granger causality test developed by Hurlin and Venet (2001) and Hansen and Rand (2006) which is suitable for panel data. This method assumed that the autoregressive coefficients and the slope coefficients are constant in a panel data VAR model. There have been a number of studies applying the approach of Hurlin and Venet (2001) in performing Granger causality tests for the panel data as Erdil and Yetkiner (2009), Tongur and Elveren (2014). According to the approach of Hurlin and Venet (2001) which consider the variable $\mathrm{x}_{\mathrm{i}, \mathrm{t}}$ is causal to the variable $\mathrm{y}_{\mathrm{i}, \mathrm{t}}$, VAR model is used to describe the data table and estimating the equation (2):

$$
\mathrm{y}_{\mathrm{i}, \mathrm{t}}=\sum_{\mathrm{k}=1}^{\mathrm{q}} \eta^{\mathrm{k}} \mathrm{y}_{\mathrm{i}, \mathrm{t}-\mathrm{k}}+\sum_{\mathrm{k}=1}^{\mathrm{q}} \gamma_{\mathrm{i}}^{\mathrm{k}} \mathrm{x}_{\mathrm{i}, \mathrm{t}-\mathrm{k}}+\mathrm{v}_{\mathrm{i}, \mathrm{t}}
$$

Where $\mathrm{t}$ denotes periods, $\mathrm{N}$ is cross section units and $\mathrm{i} \in[1, \mathrm{~N}] . \mathrm{x}_{\mathrm{i}, \mathrm{t}}$ and $\mathrm{y}_{\mathrm{i}, \mathrm{t}}$ are covariance stationary variables. $\eta^{\mathrm{k}}$ and $\gamma_{\mathrm{i}}^{\mathrm{k}}$ are assumed to be constant over time.

This paper uses three methods of panel unit root test, including LLC (Levin et al., 2002), IPS (Im et al., 2003) and Breitung (Breitung, 2000). The result of unit root tests showed some variables in the equation (1) are non-stationary at the level. However, all the inspection for first difference of these variables stopped with all testing at the statistical significance level of $1 \%$. Therefrom, we continued to use the first difference of these variables for Granger causality test in the next step. 
Table 5. Result of panel unit root tests at level

\begin{tabular}{lccccc}
\hline & INV & GDPG & REM & GE & OPENNESS \\
\hline LLC & $2.23138^{* *}$ & $-5.12438^{* * *}$ & 0.06375 & $-2.53861 * * *$ & $-1.32370 *$ \\
IPS & $1.74283^{* *}$ & $-6.68916^{* * *}$ & 0.68085 & $-3.96315^{* * *}$ & 1.93544 \\
Breitung & $-1.96612^{* *}$ & $-9.05637^{* * *}$ & -0.45429 & -0.70561 & 5.07985 \\
\hline
\end{tabular}

Notes: * significant at $10 \%$;* significant at $5 \%$; *** significant at $1 \%$.

Table 6. Result of panel unit root tests at first difference

\begin{tabular}{lccccc}
\hline & $\Delta \mathrm{INV}$ & $\Delta \mathrm{GDPG}$ & $\Delta \mathrm{REM}$ & $\Delta \mathrm{GE}$ & $\Delta$ OPENNESS \\
\hline LLC & $-18.5621 * * *$ & $-4.14250^{* * *}$ & $-12.6246 * * *$ & $-21.2825 * * *$ & $-8.74867 * * *$ \\
IPS & $-13.4183 * * *$ & $-18.1481 * * *$ & $-4.98369 * * *$ & $-16.0387 * * *$ & $-13.1924 * * *$ \\
Breitung & $-14.0737 * * *$ & $-14.6488^{* * *}$ & $-8.26342^{* * *} *$ & $-21.2825 * * *$ & $-2.83548 * * *$ \\
\hline
\end{tabular}

Notes: $*$ significant at $10 \% ; * *$ significant at $5 \% ; * * *$ significant at $1 \%$.

By application of the methodology developed by Hurlin and Venet (2001), we use the Granger causality tests to examine the causal relation between private investment and the explanatory variables. Two-time stationary VAR models are written as follows:

$$
\begin{aligned}
& \Delta \mathrm{y}_{\mathrm{i}, \mathrm{t}}=\sum_{\mathrm{k}=1}^{\mathrm{p}} \eta^{\mathrm{k}} \Delta \mathrm{y}_{\mathrm{i}, \mathrm{t}-\mathrm{k}}+\sum_{\mathrm{k}=1}^{\mathrm{p}} \gamma_{\mathrm{i}}^{\mathrm{k}} \Delta \mathrm{x}_{\mathrm{i}, \mathrm{t}-\mathrm{k}}+\mathrm{v}_{\mathrm{i}, \mathrm{t}} \\
& \Delta \mathrm{x}_{\mathrm{i}, \mathrm{t}}=\sum_{\mathrm{k}=1}^{\mathrm{p}} \eta^{\mathrm{k}} \Delta \mathrm{x}_{\mathrm{i}, \mathrm{t}-\mathrm{k}}+\sum_{\mathrm{k}=1}^{\mathrm{p}} \gamma_{\mathrm{i}}^{\mathrm{k}} \Delta \mathrm{y}_{\mathrm{i}, \mathrm{t}-\mathrm{k}}+\mathrm{v}_{\mathrm{i}, \mathrm{t}}
\end{aligned}
$$

The optimal lag of VAR model is selected based on the recommendations of some indexes, including the Akaike Information Criteria (AIC), Schwarz Criterion (SC), HannanQuinn Information Criterion (HQ), Final prediction error (FPE) Likelihood ratio and (LR). The result of Granger causality tests between private investment and the explanatory variables are presented in Table 7 below.

Table 7. Results of panel Granger causality tests

\section{Rem and Private Investment}

\begin{tabular}{lcc}
\hline \multirow{2}{*}{$\mathrm{Lag}=3$} & $\mathrm{REM} \rightarrow \mathrm{INV}$ & $\mathrm{INV} \rightarrow \mathrm{REM}$ \\
& $4.87446^{* * *}$ & 0.94020 \\
\hline
\end{tabular}

Economic growth rate and Private Investment

\begin{tabular}{lll}
\hline & GDPG $\rightarrow$ INV & INV $\rightarrow$ GDPG \\
Lag $=1$ & $8.72260^{* * *}$ & $12.1678^{* * *}$
\end{tabular}

Government expenditure and Private Investment

\begin{tabular}{lcl}
\hline Lag $=5$ & GE $\rightarrow$ INV & INV $\rightarrow$ GE \\
& $1.96866^{*}$ & $2.20475^{* * *}$ \\
\hline \multicolumn{2}{l}{ Trade openness and Private Investment } & \\
\hline \multirow{2}{*}{ Lag $=6$} & OPENNESS $\rightarrow$ INV & INV $\rightarrow$ OPENNESS \\
& $2.93394^{*}$ & $1.92418^{*}$ \\
\hline
\end{tabular}

Notes: $*$ significant at $10 \% ; * *$ significant at $5 \% ; * * *$ significant at $1 \%$.

The results from Table 7 indicate the existence of only one-way Granger causality from remittance to private investment in Asian and the Pacific developing countries. It shows 
that remittance inflows increase private investment and this effect is statistically significant at the $1 \%$ level. It is found that there exists two-ways Granger causality between economic growth rate and private investment in the case of Asia and the Pacific developing countries at the significance level of $1 \%$. Accordingly these results, the Granger test statistic indicates that there is a two-ways causal relationship between government expenditure and private investment. The statistical significance is $1 \%$ from private investment to government expenditure but it only is $10 \%$ from government expenditure to private investment. Finally, the two-ways causality exists between trade openness and private investment with $10 \%$ statistical significance, however, this causal relationship seems quite weak.

\section{Conclusions}

Unlike the previous studies regarding remittance, our research attempts to investigate the relationship between remittance and private investment with a sample of 30 Asian and the Pacific developing countries in the period from 1985 to 2013. Two regression methods, including OLS and 2-SLS, were applied to examine this relationship. The results showed that higher remittance inflows raise private investment in these countries. In particular, results from two estimation methods in this research showed that there is a positive relationship between remittances and private investment. The research results complement and contribute to the literature on the impact of remittances in the economy. The research findings also provide useful information about the impact of remittances on private investment; thenceforth, the policy-makers in these countries can enhance the effectiveness of planning and operating policies for promotion private investment due to the upward trend in remittance inflows in Asia and the Pacific region.

\section{References}

Acosta, P., Calderón, C., Fajnzylber, P., Lopez, H., 2008. What is the Impact of International Remittances on Poverty and Inequality in Latin America?. World Development, Vol. 36, No. 1, pp. 89-114.

Adams, J. R. H., Cuecuecha, A., (2010). Remittances, Household Expenditure and Investment in Guatemala. World Development, Vol. 38, No. 11, pp. 1626-1641.

Adams, J. R. H., Cuecuecha, A., (2013). Remittances, Household Expenditure and Investment in Ghana. World Development, Vol. 50 (C), pp. 24-40.

Adams, S., (2009). Foreign Direct investment, domestic investment, and economic growth in Sub-Saharan Africa. Journal of Policy Modeling, Vol. 31, No.6, pp. 939-949.

Aggarwal, R., Kunt, A. D., Pería, M. S. M., (2011). Do remittances promote financial development?. Journal of Development Economics, Vol. 96, No. 2, pp. 255-264.

Ahamada, I., Coulibaly, D., (2013). Remittances and growth in Sub- Saharan African countries: Evidence from a panel causality test. Journal of International Development, Vol. 25,No. 3, pp. 310-324.

Baldé, Y., (2011) The Impact of Remittances and Foreign Aid on Savings/Investment in SubSaharan Africa. African Development Review, Vol. 23, No. 2, pp. 247-262.

Ball, C. P., Lopez, C., Reyes, J., (2012). Remittances, Inflation and Exchange rate regimes in Small open Economies. MPRA paper No. 39852, University Library of Munich, Germany.

Bayangos, V., Jansen, K., (2011). Remittances and Competitiveness: The Case of the Philippines. World Development, Vol. 39, No.10, pp. 1834-1846.

Beine, M., Lodigiani, E., Vermeulen, R., (2012). Remittances and financial openness. Regional Science and Urban Economics, Vol. 42, No. 5, pp. 844-857. 
Breitung, J. (2000) The Local Power of Some Unit Root Tests for Panel Data. In: B. Baltagi (Ed), Advances in Econometrics: Nonstationary Panels, Panel Cointegration, and Dynamic Panels, JAI Press, Amsterdam, Vol. 15, pp. 161-178.

Berdiev, A. N., Kim, Y., Chang, C. P., (2013). Remittances and Corruption. Economic Letters, Vol. 118, No. 1, pp. 182-185.

Chowdhury, M. B., (2011). Remittances flow and financial development in Bangladesh. Economic Modelling, Vol. 28, No. 6, pp. 2600-2608.

Combes, J., Ebeke, C., (2011). Remittances and Household Consumption Instability in Developing countries. World Development, Vol. 39, No. 7, pp. 1076-1089.

Conway, D., Cohen, J, H., (1998). Consequences of Migration and Remittances for Mexican Transnational Communities. Economic Geography, Vol. 74, No. 1, pp. 26-44.

Cooray, A., (2012). Migrant remittances, financial sector development and the government ownership of banks: Evidence from a group of non-OECD economies. Journal of International Financial Markets, Institutions \& Money, Vol. 22, No. 4, pp. 936-957.

Davis, J., Lopez-Carr, D., (2014). Migration, remittances and smallholder decision-making: Implications for land use and livelihood change in Central America. Land Use Policy, Vol. 36, pp. 319-329

Giuliano, P., Ruiz-Arranz, M., (2009). Remittances, financial development, and growth. Journal of Development Economics, Vol. 90, pp. 144-152.

Gupta, S., Pattillo, C. A., Wagh, S., (2009). Effect of Remittances on Poverty and Financial Development in Sub-Sahara Africa. World Development, Vol. 37, No. 1, pp. 104-115.

Im, K. S., Perasan, M. H., and Shin, Y. (2003) Testing Unit Roots in Heterogeneous Panels, Journal of Econometrics, Vol. 115, No.1, pp. 53-74.

Imai, K. S., Gaiha, R., Ali, A., Kaicker, N., (2014). Remittances, growth, and poverty: New evidence from Asian countries. Journal of Policy Modeling, Vol. 36, No. 3, pp. 524-538.

Khan, Z. S., Islam, S., (2013). The effects of Remittances on Inflation: Evidence from Bangladesh. Journal of Economics and Business Research, Vol. 19, No. 2, pp. 198-208.

Levin, A., Lin C. F. and Chu, C., (2002) Unit Root Tests in Panel Data: Asymptotic and Finite-Sample Properties, The Review of Financial Studies, Vol. 108, No.1, pp. 1-24.

Massey, D., Parrado, E., (1998). International migration and business formation in Mexico. Social Science Quarterly, Vol. 79, No.1, pp. 1-20.

Narayan, P., Narayan, S., Mishra, S., (2011). Do remittances induce inflation? Fresh evidence from developing countries. Southern Economic Journal, Vol. 77, No.4, pp. 914-933.

Nyamongo, E. M., Misati, R. N., Kipyegon, L., Ndirangu, L., (2012). Remittances, financial development and economic growth in Africa. Journal of Economic and Business, Vol. 64, No.3, pp. 240-260.

Mallick, H (2012), Inflow of remittances and private investment in India. The Singapore Economic Review, Vol. 57, No. 1, pp. 1-22.

Rao, B., Hassan, G., (2011). A panel data analysis of the growth effects of remittances. Economic Modelling, Vol. 28, No. 1-2, pp. 701-709.

Salas, V. B., (2014). International Remittances and Human Capital Formation. World Development, Vol. 59, pp. 224-237.

Töngür, Ü., and Elveren, A. Y. (2014) Deunionization and pay inequality in OECD Countries: A panel Granger causality approach, Economic Modelling, Vol.38 (C), pp. 417425. 


\section{APPENDIX}

List of countries used in study sample :

Armenia, Azerbaijan, Bangladesh, Bhutan, Cambodia, China, Fiji, Georgia, Hong Kong, India, Indonesia, Iran, Kazakhstan, Kiribati, Korea. Rep, Kyrgyz Republic, Lao, Macao, Malaysia, Maldives, Mongolia, Nepal, Pakistan, Papua New Guinea, Philippines, Samoa, Solomon Islands, Sri Lanka, Tajikistan, Thailand, Turkey and Vietnam. 